\title{
DEVELOPMENT OF A NEW-INVENTED SYSTEM FOR TREE-BRANCHES CHOPPING
}

\author{
A. A. El Attar ${ }^{(1)}$, A.A. Bahnasawy ${ }^{(2)}$, \\ I. Yehia ${ }^{(3)}$, S. A. Aly ${ }^{(4)}$ and T. A. Hassan ${ }^{(5)}$
}

\begin{abstract}
The aim of this research is to develop, construct and evaluate a newinvented system for tree-branches chopping. The chopping system consists of frame, tires, draw-bar, $15-\mathrm{kW}$ electrical motor, feeding, cutting, chopping units and suction-fan. The main results in this study can be summarized in the following points:

- The maximum average of chopping length of $19 \mathrm{~mm}$ was obtained by using chopping-knives speed of $900 \mathrm{rpm}(27.31 \mathrm{~m} / \mathrm{s})$, concave-hole diameter of $20 \mathrm{~mm}$ and tree-branch diameter of $50 \mathrm{~mm}$. Meanwhile, the minimum average of chopping length of $6 \mathrm{~mm}$ was obtained by using chopping-knives speed of $1200 \mathrm{rpm}(36.92 \mathrm{~m} / \mathrm{s})$, concave-hole diameter of $14 \mathrm{~mm}$ and tree-branch diameter of $20 \mathrm{~mm}$ (at constant clearance of $5 \mathrm{~mm}$, moisture-content of $10 \%$, cutting-knives speed of $450 \mathrm{rpm}$ and feeding-drums speed of $10 \mathrm{rpm}$ ).

- The minimum productivity of $238 \mathrm{~kg} / \mathrm{h}$ was obtained by using chopping-knives speed of $900 \mathrm{rpm}(27.31 \mathrm{~m} / \mathrm{s})$, concave-hole diameter of $14 \mathrm{~mm}$ and tree-branch diameter of $50 \mathrm{~mm}$. Meanwhile, the maximum machine productivity of $667 \mathrm{~kg} / \mathrm{h}$ was obtained by using chopping-knives speed of $1200 \mathrm{rpm}(36.92 \mathrm{~m} / \mathrm{s})$, concave-hole diameter of $20 \mathrm{~mm}$ and tree-branch diameter of $20 \mathrm{~mm}$ (at constant clearance of $5 \mathrm{~mm}$, moisture-content of $10 \%$, cutting-knives speed of $450 \mathrm{rpm}$ and feeding-drums speed of $10 \mathrm{rpm}$ ).

- The operation and production costs at chopping-knives speed of 1200 $\mathrm{rpm}(36.92 \mathrm{~m} / \mathrm{s})$ were 17.42 - 18.71 L. E./h and $28.01-68.98$ L.E./ton for all tested tree-branch and concave-hole diameters.
\end{abstract}

This study is a part of outcomes from Ph.D. Thesis.

(1) Eng., Ministry of Supply and Internal Trade.

(2), (4) and (5) Prof. and Head, and Prof. of Ag. Eng. Dept., Faculty of Ag., Moshtohor, Benha Univ.

(3) Prof. and Head of Mech. Systems of Agricultural Operations. Ag. Eng., Res. Inst. 


\section{INTRODUCTION}

7 he agricultural crop residues epically horticultural are considered one of the most important problems that face the environmental life and farmers in Egypt. The mechanical treatment (cutting or chopping and briquetting processes) is the primary step and suitable solution for solving this problem.

The first step towards solving this problem is to cut, crush and mill these lignocelluloses materials in order to be used as raw materials in several processes. FAO (2008) Ghanem and Basiouny (2010) stated that there are many problems associated with agricultural waste. These problems are the difficulty of decomposition due to higher content of cellulose materials, waste spread over large areas which requires taking into account the assembly and transport process, low specific density of the waste, which leads to a problem in the storage, economic motives for the collection and transport not available, occupy large areas of the field during storage, containing rats and harmful insects, a good environment to ignite fires, and cause harmful environmental pollution when burned to humans, animals and field.

The total quantity of agricultural residues in Egypt is about 79 million ton. The quantity of palm, fruit and ornamental tree residues in year of 2014 are 4.3, 6.7 and 4.6 million ton respectively (Bulletin of Central Administration for Agricultural Extension Service, 2015)

From a point of view, the tree-branches chopping is necessary as a pretreatment to different uses. Mechanical treatment of the tree branches is done in order to convert it to small pieces, which are suitable for compost and energy briquetting. The tree-branches chopping process can be done by using variable types of chopping machines, but the productivity of these choppers is still little, not covering the manufactures needs in addition to the high operation and production cost of the chopping process.

Various types of size reduction equipment are available in the market. Based on the classification of size reduction equipment done by Schubert et al. (2004) and Woldt et al. (2004), Miu et al. (2006), an extended layout of this classification and suggested hammermill, knife mill, and disc mill are the proper equipment for biomass comminution. 
Before turning branches into available energy, it needs special processing equipment to chop the branches into small pieces. This study introduces a new-invented system for tree-branch chopping which is biomass power generation preprocessing equipment. Most of the traditional chopping mechanism is a cutter disc structure and circular cutter structure. The cutter disc structure chopping mechanism has a big power and huge body that make the whole machine very heavy. So, the development of a newinvented system for tree-branches chopping can solve these two problems.

Abede Alrahman (2013) tested a developed knife for hammer mill chopper. It was found that by increasing concave-hole diameter from 5 to $10 \mathrm{~mm}$, the power requirement decreased "from 5.26 to $5.13 \mathrm{~kW}$ ", for rice straw and similar figures for corn stoves, etc...

Abo-Elasaad (2015) and Abo-Habaga et al. (2016) developed a rice straw bales chopper. It was found that the maximum value of power requirement and specific energy about $7.17 \mathrm{~kW}$ and $7.75 \mathrm{~kW}$. h/t were obtained by using cutting-knives speed of $1260 \mathrm{rpm}(26.4 \mathrm{~m} / \mathrm{s})$ and 750 rpm $(15.71 \mathrm{~m} / \mathrm{s})$, platform tilt-angle of 30 degree with using 24 cutting knives, respectively. Whereas, the minimum value of power requirement and specific energy about $3.72 \mathrm{~kW}$ and $5.07 \mathrm{~kW} . \mathrm{h} / \mathrm{t}$ were obtained by using cutting-knives speed of $750 \mathrm{rpm}(15.71 \mathrm{~m} / \mathrm{s})$ and $1260 \mathrm{rpm}(26.4$ $\mathrm{m} / \mathrm{s}$ ), platform tilt-angle of 20 degree with using 12 cutting knives respectively.

Okasha et al. (2015) found that the cutting productivity increased with increasing cutting-drum speed. For example the productivities were 107.1 and $150.2 \mathrm{~kg} / \mathrm{h}$ with increasing cutting-drum speed from 1600 to 2200 rpm for $1.5 \mathrm{~cm}$ concave holes diameter.

\section{The objectives of this research are:}

- Developing, constructing and testing a new-invented system for treebranches chopping.

- Studying the performance factors, such as "feeding-drums, cutting and chopping-knife speeds, tree-branches diameter and moisture content, concave-hole diameter and clearance" on cutting and chopping length, machine capacity, power requirements and cost of new-invented system for tree-branches chopping. 


\section{MATERIALS AND METHODS}

\section{2-1- Materials.}

\section{2-1-1 The new invented system for tree-branches chopping:}

The developed new-invented system for tree-branches chopping photograph views are shown in fig. 1 . The developed system consists of the following parts:

(1) Frame: The frame was made of L-section steel with dimensions of 70 x $70 \times 7 \mathrm{~mm}$. The overall length, width and height of frame are 1935, 680 and $740 \mathrm{~mm}$ respectively.

(2) Stands: Four stands are used to adjust the stability of the machine. The stands were made of iron square-tubes with thickness of $3 \mathrm{~mm}$. Each stand consists of two telescopic tubes. The internal small tube has dimensions of $80 \times 80 \times 600 \mathrm{~mm}$ and the external tube has dimensions of $100 \times 100 \times 600 \mathrm{~mm}$.

(3) Tires: Two rubber tires with diameter of $680 \mathrm{~mm}$ and width of 200 $\mathrm{mm}$ were assembled with the machine frame by square shaft welded with the frame by two plates.

(4) Draw-bar: Draw-bar made of sheet iron with length of $700 \mathrm{~mm}$, width of $60 \mathrm{~mm}$ and thickness of $50 \mathrm{~mm}$. The edge of draw-bar was welded with center of the frame. The other edge of bar has a hole with diameter of $30 \mathrm{~mm}$ to be trailed by a tractor.

\section{(5) Feeding unit:}

The feeding-unit assembly is shown in fig. 2. It consists of the following parts:

(5-a) Feeding housing: The feeding housing was made of sheet steel with $20 \mathrm{~mm}$ thickness. The top side length and width are 500 and $400 \mathrm{~mm}$ respectively. The bottom side length and width are 500 and $500 \mathrm{~mm}$ respectively. And the right and left sides width and height are 500 and $450 \mathrm{~mm}$ respectively. The overall length, width and height of feeding housing are $\bullet \cdots, 54 \cdot$ and $010 \mathrm{~mm}$ respectively.

(5-b) Feeding drums: The two fluted feeding-drums were made of steel tube with $170 \mathrm{~mm}$ diameter, $7 \mathrm{~mm}$ thickness and $400 \mathrm{~mm}$ length. The flute width, height and pitch are 3.5, 3.5 and $5 \mathrm{~mm}$ respectively. The gap between the two feeding-drums was $15 \mathrm{~mm}$. The feeding-drum 
shafts diameter and length were $70-50$ and $56 \mathrm{~mm}$ respectively. The two drums were assembled inside feeding housing.

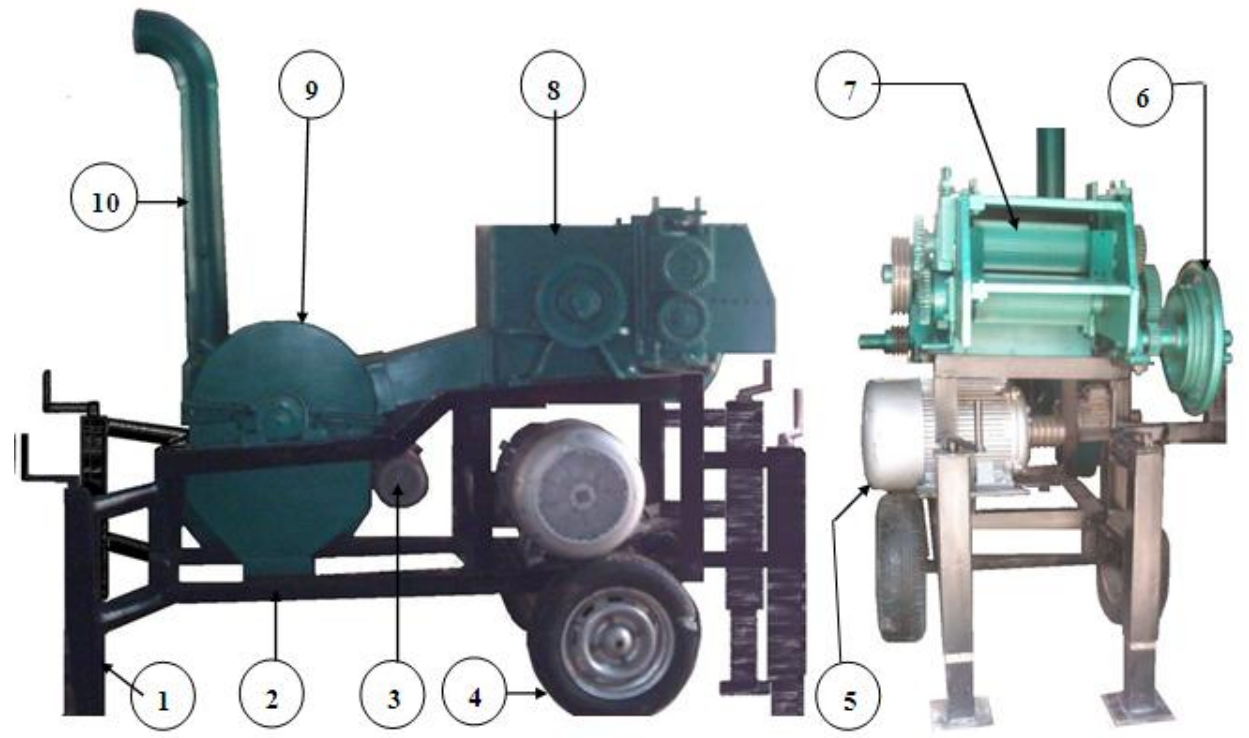

Fig. 1: Photograph views of the new invented-system for treebranches chopping.

(1) Stand, (2) Frame, (3) Fan 1-hp motor, (4) Tire, (5) 20-hp motor,

(6) Power transmission, (7) Feeding mechanism, (8) Cutting mechanism, (9)

Chopping mechanism and (10) Duct.

(5-c) Pressing springs: Four pressing springs with $50 \mathrm{~mm}$ diameter, 10 $\mathrm{mm}$ thickness and $100 \mathrm{~mm}$ length were hinged in the top of two sides of the feeding drums, as shown in fig. 2. Each two springs were hinged on the top of sides of upper feeding-drum bearing. The tree branch diameters higher than the gap between feeding drums push the upper drum by pressing springs.

(6) Cutting unit:

The cutting-unit assembly is shown in fig. 3. It consists of the following parts:

(6-a) Cutting-unit housing: The cutting-unit housing was made of sheet steel with $20 \mathrm{~mm}$ thickness. The top and bottom-sides length and width are 500 and $500 \mathrm{~mm}$ respectively. And the right and left sides have length and width 500 and $500 \mathrm{~mm}$ respectively. The overall length, width and height of the housing cutting unit are 500, 540 and $500 \mathrm{~mm}$ respectively. 
(6-b) Rotating cutting-knives: The three rotating cutting-knives were made of alloy steel "K100" with $20 \mathrm{~mm}$ thickness, $80 \mathrm{~mm}$ width and $400 \mathrm{~mm}$ length. The knives were assembled with plates welded on star discs. Each knife has five holes with $6 \mathrm{~mm}$ diameter. The steel type of the cutting knife is branded "Bohler K100 or DIN 1.2080

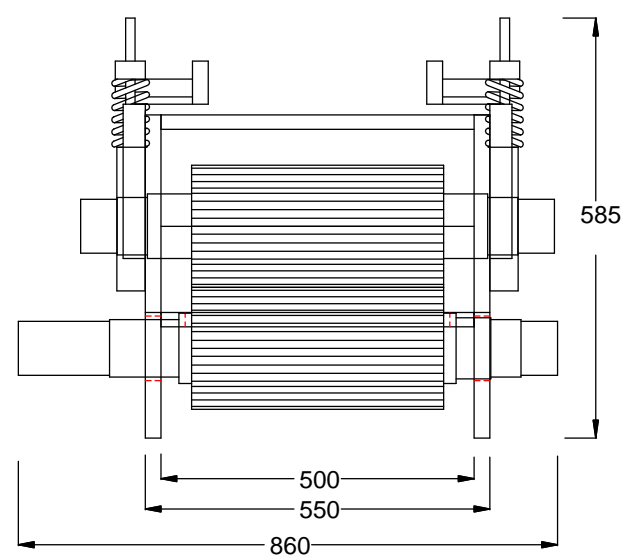

Side view

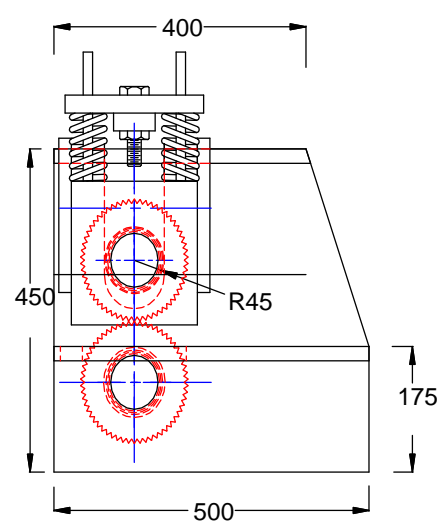

Elevation view

Dim. in $\mathrm{mm}$

Fig. 2: Assembly views of the feeding unit.

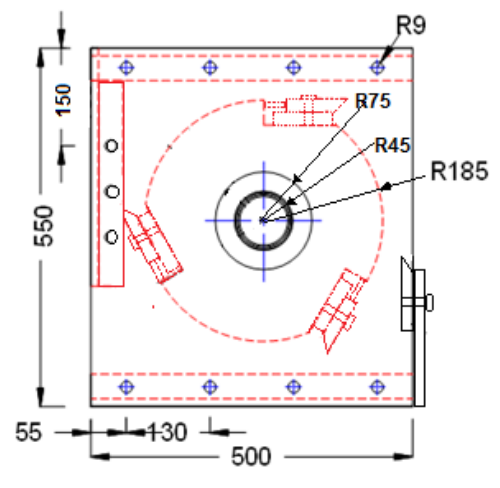

Elevation

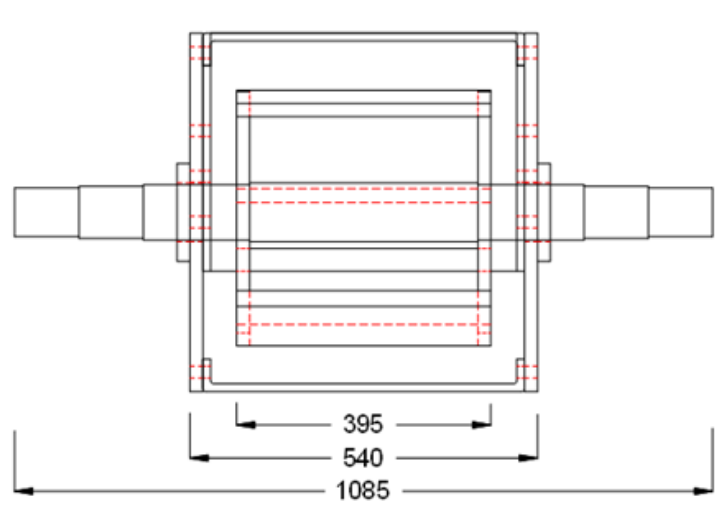

Side view

Fig. 3: Assembly drawing of the cutting unit. 
Table 1: The chemical composition of cutting knives alloy-steel "K100" (Bohler Co. - 2006).

\begin{tabular}{|c|c|c|c|c|c|}
\hline \multicolumn{6}{|c|}{ The elements, $\%}$. \\
\hline $\mathrm{C}$ & $\mathrm{Si}$ & $\mathrm{Mn}$ & $\mathrm{Cr}$ & $\mathrm{Ni}$ & $\mathrm{W}$ \\
\hline 1.98 & 0.19 & 0.32 & 11.84 & 0.18 & 0.05 \\
\hline
\end{tabular}

The hardness of the knife steel was in the range of $63-65 \mathrm{HRC}$ (Hardness Rockwell Scale).

X210Cr12". The chemical compositions of cutting knives alloy-steel "K100" is shown in table 1.

(6-c) Star discs and plates: Three star-discs made of sheet steel with $370 \mathrm{~mm}$ diameter, $20 \mathrm{~mm}$ thickness. Each disc has three grooves. The disc-groove length, width and height are 120, 80 and $20 \mathrm{~mm}$ respectively. Three plates are welded with grooves of three discs. Each plate has 5 sluts with dimensions of $60 \times 20 \mathrm{~mm}$.

(6-d) Fixed knife: The three fixed knife was made of alloy steel "K100" with

$20 \mathrm{~mm}$ thickness, $80 \mathrm{~mm}$ width and $400 \mathrm{~mm}$ length. (7) Conveying tunnel: The conveying tunnel connects the outlet of cutting unit and inlet of chopping unit. The tunnel was made of sheet metal with thickness of $2 \mathrm{~mm}$. The dimensions of the tunnel side connected with chopping-outlet of cutting unit are $500 \times 200 \mathrm{~mm}$. And the dimensions of tunnel side connected with inlet of chopping unit are $200 \times 200 \mathrm{~mm}$.

\section{(8) Chopping unit:}

The chopping-unit assembly drawing is shown in fig. 4. The chopping unit consists of the following parts:

(8-a) Chopping housing: The circular feeding-housing was made of sheet steel with $6 \mathrm{~mm}$ thickness. The housing divides into two parts. The 60 plates with dimensions of $200 \times 15 \times 15 \mathrm{~mm}$ were welded inside the top of upper half of feeding housing. The top and bottom side length and width are 620 and $200 \mathrm{~mm}$ respectively. The overall length, width and height of chopping housing are 1000, 680 and 270 $\mathrm{mm}$ respectively. 
(8-b) Chopping-unit shaft and flanges: Chopping-unit shaft was made of steel with maximum diameter of $98 \mathrm{~mm}$ and length of $809 \mathrm{~mm}$. The chopping-unit shaft is mounted with machine frame by two ballbearings. Five steel flanges with diameter of $320 \mathrm{~mm}$ and thickness of $8 \mathrm{~mm}$ were welded with chopping unit shaft. Each flange has 4 holes with diameter of $20 \mathrm{~mm}$. The flanges spacing was $20 \mathrm{~mm}$.

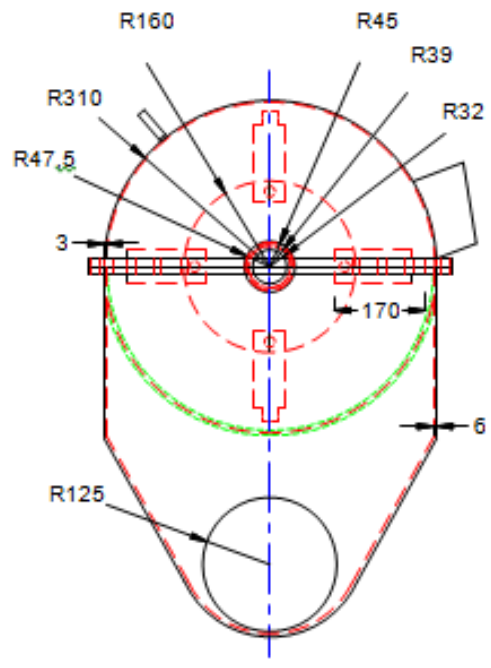

Elevation view

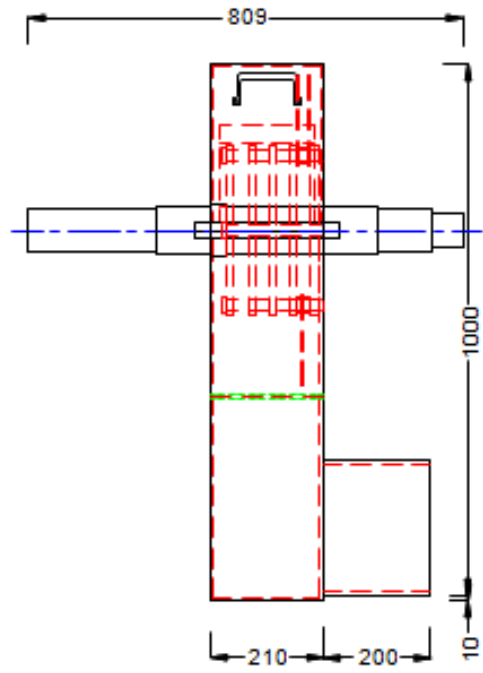

Side view

Dim. in mm.

Fig. 4: Assembly views of the cutting unit.

(8-c) Chopping knives, sleeve rings and pins: Twenty four free chopping-knives were made of steel sheet. Each chopping knife has thickness of $6 \mathrm{~mm}$, length of $170 \mathrm{~cm}$ and width of $60 \mathrm{~mm}$. The chopping knives statically and dynamically were balanced with respect to the chopping-shaft assembly at private workshop. The chopping-knives were hinged between flanges by 24 sleeve rings and 4 pins. The twenty four free-knives were arranged with 4 rows. The first pairs faced-rows have 16 knives (each row has 8 knives) and the other pairs faced-rows have 8 knives (each row has 4 knives). The knife existing in the row which has 16 knives was 
hinged between two flanges by one sleeve rings inserted between two knives. Meanwhile, the knife exist in the row which have 8 knives was hinged between two flanges by two sleeve rings in two knife sides. Eight sleeve rings had length of $7 \mathrm{~mm}$, inlet diameter of $21 \mathrm{~mm}$ and outer diameter of $30 \mathrm{~mm}$. Meanwhile, sixteen sleeverings had length of $6 \mathrm{~mm}$ and the same diameters. Each pin has diameter of $20 \mathrm{~mm}$ and total length of $190 \mathrm{~mm}$. The pin head height and diameter are 10 and $26 \mathrm{~mm}$ respectively. Each pin fixed with the flange in the other side of pin head by a vertical Allen socket head grub-type screw with diameter of $5 \mathrm{~mm}$ and length of $10 \mathrm{~mm}$.

(9) Connected tubes: The connecting tubes connect the outlet of chopping unit and inlet of blower fan. The connecting tubes were made of sheet metal with diameter of $200 \mathrm{~mm}$ and thickness of 3 $\mathrm{mm}$. The first connecting tube welded with chopping unit has length of $200 \mathrm{~mm}$. The second tube was welded with blower-fan housing with length of $200 \mathrm{~mm}$. The two connecting tubes were connected face to face and warped with rubber coil. The rubber coil was held with two connecting tubes by clamp.

(10) Suction and expulsion unit: The suction and expulsion unit consists of blower-fan assembly and expulsion duct. The blower fan assembly consists of the following parts:

(10-a) Housing: made of sheet iron with thickness $3 \mathrm{~mm}$. The maximum length, width and height of the blower-fan housing are 620, 378 and $945 \mathrm{~mm}$ respectively. Figs. 1 and 2 show views and photograph of the blower-fan housing.

(10-b) Blower fan: made of sheet iron with thickness of $\mathrm{mm}$. The diameter and width of the fan are 350 and $100 \mathrm{~mm}$ respectively. The blower fan has 14 vanes. The vanes were made of sheet iron with $3 \mathrm{~mm}$ thickness.

(10-c) Blower-fan shaft: made of steel with diameter of $24 \mathrm{~mm}$ and maximum length of $300 \mathrm{~mm}$.

(10-d) The expulsion duct: is made of steel tube with diameter of 150 $\mathrm{mm}$, length of $1020 \mathrm{~mm}$ and thickness of $3 \mathrm{~mm}$.

(11) Electrical motors: The investigated chopper was designed to use two power movers as follows: 
(11-a) First motor: three phase induction electrical-motor of $15.4 \mathrm{~kW}$ (20 hp) and $970 \mathrm{rpm}$ was assembled with the frame to drive feeding, cutting and chopping units only in experimental tests by means of pulleys, v-belts and gear drives. After the optimum speeds, all machine units can be operated by the $15.4 \mathrm{~kW}$ motor. The electrical motor is equipped with a movable base using four bolts to be able to replace and change the tested pulleys.

(11-b) Second motor: single phase induction motor of $0.75 \mathrm{~kW}(1 \mathrm{hp})$ and $1400 \mathrm{rpm}$ was assembled with the blower-fan assembly base to drive the suction blower-fan only in experimental tests. Primary experiment-tests for blower-fan speeds were conducted to determine the optimum speed which was $1400 \mathrm{rpm}$. This motor is equipped with fixed base using four bolts.

(12) Power transmission-unit: The power was transmitted from the electrical motor by means of pulleys and v-belts drives. The motorshaft pulley with diameter " $\mathrm{D}_{1}$ " of $120 \mathrm{~mm}$ is on the choppingknives shaft pulleys with diameter " $\mathrm{D}_{2}$ " of 97, 106, 116 and $130 \mathrm{~mm}$. The chopping-knives shaft carries a pulley with tested diameters " $\mathrm{D}_{3}$ " of $140 \mathrm{~mm}$ at the other direction of chopping-unit shaft. The last pulley " $\mathrm{D}_{3}$ " is connected with pulley with tested diameters " $\mathrm{D}_{4}$ " of 228. 253, 285 and $325 \mathrm{~mm}$ which was carried on cutting-unit shaft. The cutting-knives shaft carries a pulley of diameter " $\mathrm{D}_{4}$ " of $100 \mathrm{~mm}$ at the other direction of cutting-unit shaft. The last pulley " $\mathrm{D}_{5}$ " is connected with pulley with tested diameters " $\mathrm{D}_{6}$ " of 220. 263, 360 and $600 \mathrm{~mm}$ which was carried on an a handle shaft. The small gear "Gear 1" with diameter $10 \mathrm{~cm}$ and number of teeth of 10 is bolted to the same handle shaft. The small gear "Gear 1" is connected with the lower drum feeding-shaft gear "Gear 2" with diameter of $60 \mathrm{~cm}$ and number of teeth 57 . The lower drum feeding shaft carries two gears with 36 teeth at two direction of it. The last two gears connected with two gears "Gear 3 and Gear 4" with 36 teeth to transmit the motion to the upper feeding-drum. The above mentioned power transmission arrangement of feedingdrum, cutting-knife and chopping-knife speeds are shown in table 2. 
The constant tested blower-fan speed of $1400 \mathrm{rpm}$ was obtained using another motor with $0.75 \mathrm{~kW}$ power and $1400 \mathrm{rpm}$ speed.

2-1-2 Tree branches: "Ficus nitida" tree-branches with diameters of 20, 30,40 and $50 \mathrm{~mm}$ and moisture content of $10 \%$ wet base were used in the experimental tests.

Table 2: Tested motor, chopping shaft pulley diameters and chopping knife speeds at constant feeding-drum speed of $10 \mathrm{rpm}$ and cutting-knives speed of $450 \mathrm{rpm}$.

\begin{tabular}{|c|c|c|c|}
\hline $\begin{array}{c}\text { Motor pulley } \\
\text { diameter, } \\
\text { mm. } \\
\left(\mathrm{D}_{1}\right)\end{array}$ & $\begin{array}{c}\text { Chopping-shaft } \\
\text { pulley diameter, } \\
\mathrm{mm} . \\
\left(\mathrm{D}_{2}\right)\end{array}$ & $\begin{array}{c}\text { Chopping- } \\
\text { knives speed, } \\
\mathrm{rpm} .\end{array}$ & $\begin{array}{c}\text { Chopping- } \\
\text { knives speed, } \\
\mathrm{m} / \mathrm{s} .\end{array}$ \\
\hline \multirow{3}{*}{120} & 130 & 900 & 27.31 \\
\cline { 2 - 4 } & 116 & 1000 & 30.35 \\
\cline { 2 - 4 } & 106 & 1100 & 33.38 \\
\cline { 2 - 4 } & 97 & 1200 & 36.42 \\
\hline
\end{tabular}

\section{2-2 Methods:}

\section{(1) Studied factors.}

The experiments were conducted to study some factors affecting the chopping-unit performance such as chopping-knives speed, concave-hole diameter, tree-branch diameter at tree-branches moisture content of $10 \%$, feeding-drum speed of $10 \mathrm{rpm}(0.083 \mathrm{~m} / \mathrm{s})$, cutting-knife speed of 450 $\mathrm{rpm}(8.47 \mathrm{~m} / \mathrm{s})$ and clearance between chopping-knife tips and choppinghousing roof is $5 \mathrm{~mm}$. The studied parameters were as follows:

(a) Chopping-knives speeds: The tested chopping-knife speeds were 900, 1000, 1100, and $1200 \mathrm{rpm}(27.31,30.35,33.38$ and $36.42 \mathrm{~m} / \mathrm{s})$.

(b) Concave-hole diameters: The tested concave-hole diameters were 14, 16, 18 and $20 \mathrm{~mm}$.

(d) Tree-branche moisture contents: The tested tree-branch moisture contents were 10, 15, 20 and $25 \%$ in wet base.

(e) Tree-branch diameters: The tested tree-branch diameters were 20, 30,40 and $50 \mathrm{~mm}$.

(2) Measurements:

(a) Average and percentage chopping-length of tree branches: Average chopping-length for tree branches produce from chopping 
unit was measured from sample of $200 \mathrm{~g}$ for each treatment. Six categories of " $<4$ ", " $4-8$ ", " $8-12$ ", " $12-16$ ", " $16-20$ " and " $>$ 20 " $\mathrm{mm}$ were measured. Also each chopping length in the sample was weighed and calculated as a percentage from the total weight of the sample.

(b) Machine productivity: Machine productivity was calculated by using the following equation:

$$
\mathrm{P}=\mathrm{W} / \mathrm{t}
$$

Where: $\mathbf{P}$ : Machine productivity, $\mathrm{kg} / \mathrm{h}, \mathbf{W}$ : Mass of the rice straw bale, $\mathrm{kg}$ and $\mathbf{t}$ : Time, $\mathrm{h}$.

(d) Power requirement and specific energy: The electrical power requirement $(\mathrm{kW})$ was calculated by using the clamp meter to measure the line current strength in Amperes (I) and potential difference values $(\mathrm{v})$. The required power of developed new invented system for tree-branches chopping with and without load $(\mathrm{P})$ was calculated according to Kurt, 1979 by using the following equation:

$$
\mathrm{P}=\sqrt{\mathbf{3}} \times \mathbf{I} \times \mathbf{V} \times \eta \times \operatorname{Cos} \theta / 1000
$$

Where: P: Power requirement for the cutting machine in $\mathrm{kW}, \mathbf{I}$ : Line current intensity in amperes, $\mathbf{V}$ : Voltage being equal to $380 \mathrm{~V}, \operatorname{Cos} \theta$ : Power factor (taken to 0.85 ), $\sqrt{3}$ : Coefficient current three phase and $\eta$ : Mechanical efficiency assumed (95\%).

The specific energy was calculated by using the following equation:

$$
\text { Specific energy, } \mathrm{kW} \cdot \mathrm{h} / \mathrm{ton}=\frac{\text { Power, } \mathrm{kW}}{\text { Productivity, ton } / \mathrm{h}}
$$

(e) Estimating the costs of using the machine: Cost of operation was calculated according to the equation given by Awady, 1978, in the following form:

$$
\mathrm{C}=\mathrm{p} / \mathrm{h}(1 / \mathrm{a}+\mathrm{i}+\mathrm{t} / 2+\mathrm{r})+(\mathrm{Ec} * \mathrm{Ep})+\mathrm{m} / 144
$$

Where: C: hourly cost, LE/h, P: price of machine, LE, h: yearly working hours, h, a: life expectancy of the machine, year, $\mathbf{i}$ : interest rate/year, $\mathbf{t}$ : taxes, (0.05), r: overheads and indirect cost ratio (0.03), Ec: Electricity consumption kW, Ep: Electricity price L.E/kW.h, m: Monthly wage and 
"144" are estimated monthly working hours. Notice that all units have to be consistent to result in L.E/h.

Production cost was calculated according to the following equation:

Production cost, L.E./ton $=\frac{\text { Operation cost, L. E./ h }}{\text { Machine productivity, ton } / \mathrm{h}}$

\section{RESULTS AND DISCUSSION}

(1) Effect of tree-branch diameter, chopping-knives speed, concave holediameter on average of chopping-length at clearance of $5 \mathrm{~mm}$, moisturecontent of $10 \%$, cutting-knives speed of $450 \mathrm{rpm}$ and feeding-drums speed of $10 \mathrm{rpm}$.

Fig. 5 shows the effect of tree-branches diameter, chopping-knives speed and concave-hole diameter on average of chopping length.

The maximum average of chopping length of $19 \mathrm{~mm}$ was obtained by using chopping-knives speed of $900 \mathrm{rpm}(27.31 \mathrm{~m} / \mathrm{s})$, concave-hole diameter of $20 \mathrm{~mm}$ and tree-branch diameter of $50 \mathrm{~mm}$. Meanwhile, the minimum average of chopping length of $6 \mathrm{~mm}$ was obtained by using chopping-knives speed of $1200 \mathrm{rpm}(36.92 \mathrm{~m} / \mathrm{s})$, concave-hole diameter of $14 \mathrm{~mm}$ and tree-branch diameter of $20 \mathrm{~mm}$ (at constant clearance of 5 $\mathrm{mm}$, moisture-content of $10 \%$, cutting-knives speed of $450 \mathrm{rpm}$ and feeding-drums speed of $10 \mathrm{rpm}$ ).

(a) Effect of tree-branches diameter.

By increasing tree-branch diameter from 20 to $50 \mathrm{~mm}$ the average of chopping length increased by 22.5 at all tested concave-hole diameters and chopping-knife speeds.

The increasing of average chopping-length of tree branches by increasing tree-branches diameter is due to increasing the volume of the branches which need number of knife hits more than the smaller branch diameters.

\section{(b) Effect of chopping-knives speed.}

By increasing chopping-knives speed from 900 to $1200 \mathrm{rpm}$ (from 27.31 to $36.92 \mathrm{~m} / \mathrm{s}$ ) the average of chopping length decreased by 12.83 at all tested concave-hole diameters and tree-branch diameters.

The decreasing of average chopping-length of tree branches by increasing chopping-knives speed is due to increasing number of hits of chopping knives to tree-branches. 
(c) Effect of concave-hole diameter.

By increasing concave-hole diameter from 14 to $20 \mathrm{~mm}$ the average of chopping length increased by $35 \%$ at all tested chopping-knife speeds and tree-branch diameters.

The increasing of average chopping-length of tree branches by increasing concave-hole diameter is due to decreasing number of hits of chopping knives to tree-branches because of escaping the branches through concave holes.

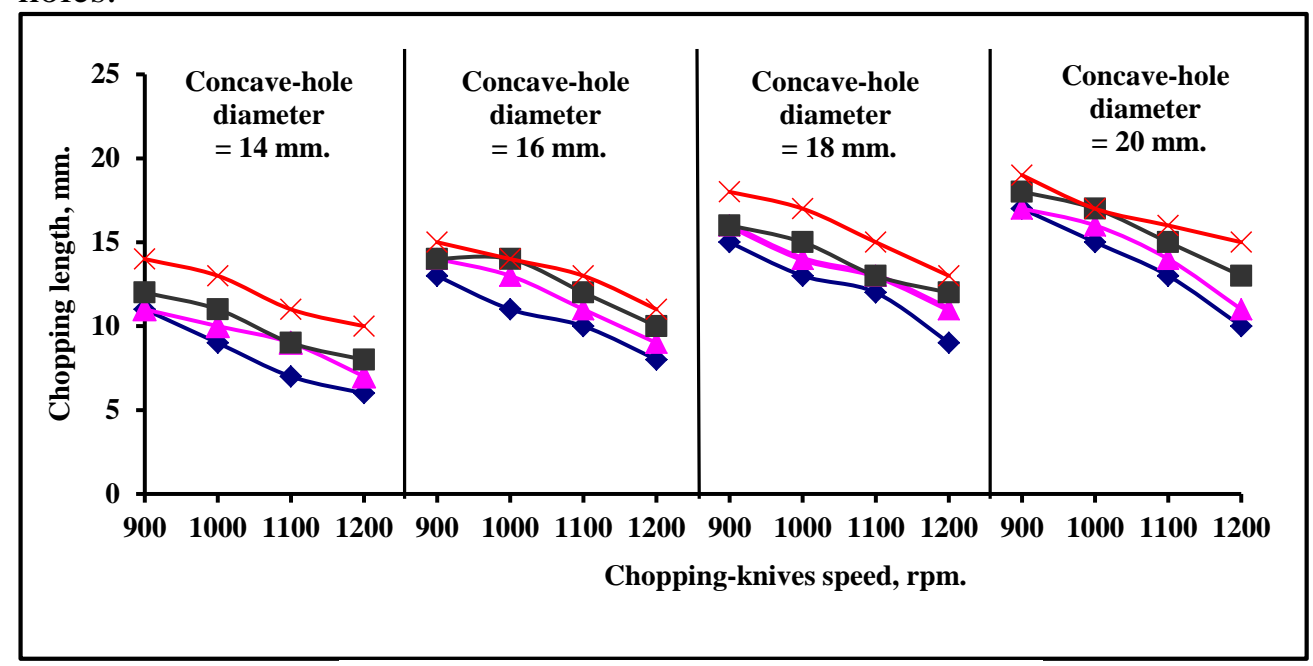

Tree-branches $\mathrm{mm}$.

$\neg-20 \leftarrow \mathbf{2 0}-\mathbf{6 0} \leftarrow \mathbf{5 0}$

Fig. 5: Effect of tree-branches diameter, chopping-knives speed and concave-hole diameter on average of cutting length by using clearance of $5 \mathrm{~mm}$ and branches moisture-content of $10 \%$.

(2) Effect of tree-branch diameter, chopping-knives speed and concave hole-diameter on chopping-length percentage at clearance of $5 \mathrm{~mm}$, moisture-content of $10 \%$, cutting-knives speed of $450 \mathrm{rpm}$ and feedingdrums speed of $10 \mathrm{rpm}$.

Figs. 6 and A-1 in appendix show the effect of tree-branches diameter, concave-hole diameter and chopping-knives speed on chopping-length percentage at clearance of $5 \mathrm{~mm}$, moisture-content of $10 \%$, choppingknives speed of $450 \mathrm{rpm}$ and feeding-drums speed of $10 \mathrm{rpm}$.

The maximum percentage of chopping-length of $82.4 \%$ was obtained with size category of $4-8 \mathrm{~mm}$ at chopping-knives speed of $1200 \mathrm{rpm}$ 
$(36.92 \mathrm{~m} / \mathrm{s})$, concave-hole diameter of $14 \mathrm{~mm}$ and tree-branches diameter of $20 \mathrm{~mm}$. Meanwhile, the minimum percentage of chopping-length of $1.9 \%$ was obtained with size category of $12-16 \mathrm{~mm}$ at chopping-knives speed of $1200 \mathrm{rpm}(36.92 \mathrm{~m} / \mathrm{s})$, concave-hole diameter of $14 \mathrm{~mm}$ and tree-branches diameter of $20 \mathrm{~mm}$.

Table 3 shows the maximum and minimum values of chopping-length percentage by contrast values of chopping-knives speed, concave-hole diameter and tree-branches diameter.

The maximum percentage of chopping-length size less than $4 \mathrm{~mm}(<4$ $\mathrm{mm}$ ) of $13.1 \%$ was obtained at chopping-knives speed of $1200 \mathrm{rpm}$ $(36.92 \mathrm{~m} / \mathrm{s})$, concave-hole diameter of $14 \mathrm{~mm}$ and tree-branches diameter of $20 \mathrm{~mm}$. Meanwhile, the minimum percentage of chopping-length size less than $4 \mathrm{~mm}(<4 \mathrm{~mm})$ of zero \% was obtained at chopping-knives speed of $900-1200 \mathrm{rpm}(27.31-36.92 \mathrm{~m} / \mathrm{s})$, concave-hole diameter of 18 $20 \mathrm{~mm}$ and tree-branches diameter of $30-50 \mathrm{~mm}$.

The maximum percentage of chopping-length size of $82.4 \%$ was obtained at chopping-knives speed of $1200 \mathrm{rpm}(36.92 \mathrm{~m} / \mathrm{s})$, concave-hole diameter of $14 \mathrm{~mm}$ and tree-branches diameter of $20 \mathrm{~mm}$.Meanwhile, the minimum percentage of chopping-length size $4-8 \mathrm{~mm}$ of zero \% was obtained at chopping-knives speed of $900-1200 \mathrm{rpm}(27.31-36.92 \mathrm{~m} / \mathrm{s})$, concave-hole diameter of $20 \mathrm{~mm}$ and tree-branches diameter of $50 \mathrm{~mm}$.

The maximum percentage of chopping-length size $8-12 \mathrm{~mm}$ of $70.9 \%$ was obtained at chopping-knives speed of $1200 \mathrm{rpm}(36.92 \mathrm{~m} / \mathrm{s})$, concave-hole diameter of $18 \mathrm{~mm}$ and tree-branches diameter of $50 \mathrm{~mm}$. Meanwhile, the minimum percentage of chopping-length size $8-12 \mathrm{~mm}$ of $2.6 \%$ was obtained at chopping-knives speed of $1200 \mathrm{rpm}(36.92 \mathrm{~m} / \mathrm{s})$, concave-hole diameter of $14 \mathrm{~mm}$ and tree-branches diameter of $20 \mathrm{~mm}$.

The maximum percentage of chopping-length size 12 - $16 \mathrm{~mm}$ of $43.1 \%$ was obtained at chopping-knives speed of $900 \mathrm{rpm}(27.31 \mathrm{~m} / \mathrm{s})$, concavehole diameter of $20 \mathrm{~mm}$ and tree-branches diameter of $40 \mathrm{~mm}$. Meanwhile, the minimum percentage of chopping-length size $12-16 \mathrm{~mm}$ of $1.9 \%$ was obtained at chopping-knives speed of $1200 \mathrm{rpm}(39.92 \mathrm{~m} / \mathrm{s})$, concave-hole diameter of $14 \mathrm{~mm}$ and tree-branches diameter of $20 \mathrm{~mm}$. 


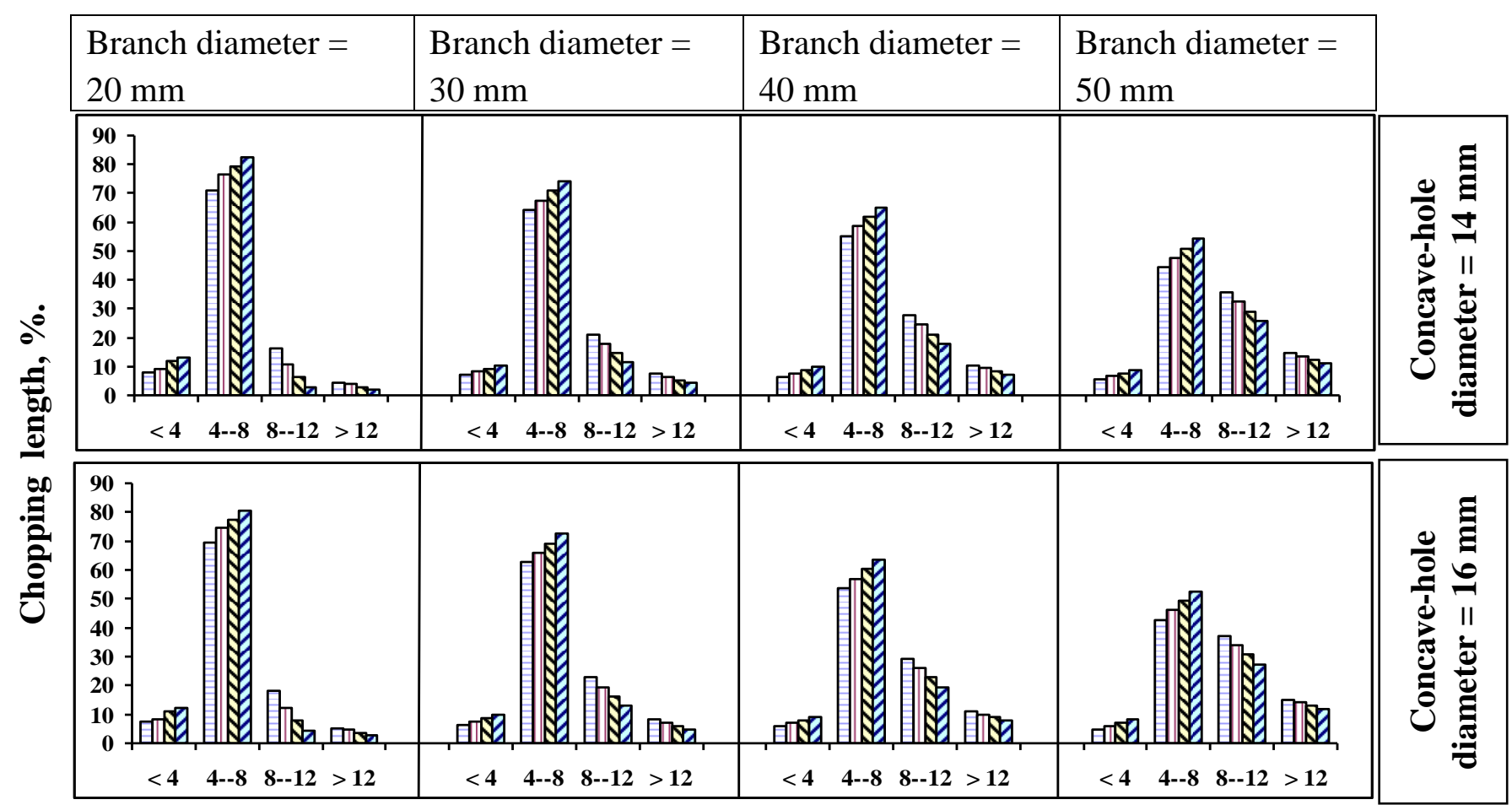

Chopping-length category, $\mathrm{mm}$.

Chopping-knives speed, rpm.

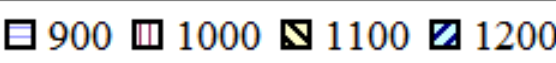

Fig. 6: Effect of chopping-knives speed and tree-branch diameter on chopping-length percentage at concave hole-diameter of 14 and $16 \mathrm{~mm}$. 
The maximum percentage of chopping-length size $16-20 \mathrm{~mm}$ of $57.1 \%$ was obtained at chopping-knives speed of $900 \mathrm{rpm}(27.31 \mathrm{~m} / \mathrm{s})$, concavehole diameter of $20 \mathrm{~mm}$ and tree-branches diameter of $50 \mathrm{~mm}$. Meanwhile, the minimum percentage of chopping-length size $16-20 \mathrm{~mm}$ of zero \% was obtained at chopping-knives speed of $900-1200 \mathrm{rpm}$ $(27.31-39.92 \mathrm{~m} / \mathrm{s})$, concave-hole diameter of $16 \mathrm{~mm}$ and tree-branches diameter of $20-50 \mathrm{~mm}$, and concave-hole diameter of $18 \mathrm{~mm}$ and treebranches diameter of $20 \mathrm{~mm}$.

Table 3: Maximum and minimum values of chopping-length percentage by contrast values of chopping-knives speed, clearance, concave-hole diameter and tree-branches diameter.

\begin{tabular}{|c|c|c|c|c|c|}
\hline $\begin{array}{l}\text { Chopping- } \\
\text { length } \\
\text { category, } \\
\text { mm. }\end{array}$ & $\begin{array}{l}\text { Maximum } \\
\text { and } \\
\text { minimum } \\
\text { values. }\end{array}$ & $\begin{array}{c}\text { Chopping } \\
\text { length, } \\
\% .\end{array}$ & $\begin{array}{l}\text { Chopping- } \\
\text { knives } \\
\text { speed, } \\
\text { rpm. }\end{array}$ & $\begin{array}{c}\text { Concave- } \\
\text { hole } \\
\text { diameter, } \\
\text { mm. }\end{array}$ & $\begin{array}{c}\text { Tree- } \\
\text { branches } \\
\text { diameter, } \\
\text { mm. }\end{array}$ \\
\hline$<4$ & \multirow{6}{*}{ 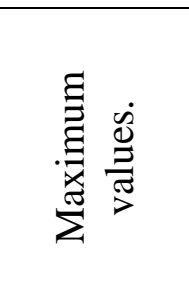 } & 13.1 & 1200 & 14 & 20 \\
\hline $4--8$ & & 82.4 & 1200 & 14 & 20 \\
\hline $8--12$ & & 70.9 & 1200 & 18 & 30 \\
\hline $12--16$ & & 43.1 & 900 & 20 & 40 \\
\hline $16-20$ & & 57.1 & 900 & 20 & 50 \\
\hline$>20$ & & 30.3 & 900 & 20 & 50 \\
\hline$<4$ & \multirow{6}{*}{$\begin{array}{l}\dot{\ddot{\Xi}} \\
\stackrel{\Xi}{\Xi} \\
\Xi \\
\Xi \\
\Xi \\
\Xi \\
\Xi\end{array}$} & 0 & $\begin{array}{l}900- \\
1200\end{array}$ & $18-20$ & $30-50$ \\
\hline $4--8$ & & 0 & $\begin{array}{l}900- \\
1200\end{array}$ & 20 & 50 \\
\hline $8--12$ & & 2.6 & 1200 & 14 & 20 \\
\hline $12--16$ & & 1.9 & 1200 & 14 & 20 \\
\hline $16-20$ & & 0 & $\begin{array}{l}900- \\
1200\end{array}$ & $\begin{array}{l}16 \\
18 \\
\end{array}$ & $\begin{array}{c}20-50 \\
20\end{array}$ \\
\hline$>20$ & & 0 & $\begin{array}{l}900- \\
1200\end{array}$ & $\begin{array}{c}14-18 \\
20\end{array}$ & $\begin{array}{l}20-50 \\
20-40\end{array}$ \\
\hline
\end{tabular}

The maximum percentage of chopping-length size more than $20 \mathrm{~mm}$ (> $20 \mathrm{~mm}$ ) of $30.3 \%$ was obtained at chopping-knives speed of $900 \mathrm{rpm}$ $(27.31 \mathrm{~m} / \mathrm{s})$, concave-hole diameter of $20 \mathrm{~mm}$ and tree-branches diameter of $50 \mathrm{~mm}$. Meanwhile, the minimum percentage of chopping-length size more than $20 \mathrm{~mm}$ (> $20 \mathrm{~mm}$ ) of zero \% was obtained at chopping-knives 
speed of $900-1200 \mathrm{rpm}(27.31-39.92 \mathrm{~m} / \mathrm{s})$, concave-hole diameter of $14-18 \mathrm{~mm}$ and tree-branches diameter of $20-50 \mathrm{~mm}$, and concave-hole diameter with tree-branches diameter of $20-40 \mathrm{~mm}$.

(3) Effect of tree-branch diameter, chopping-knives speed, concave hole-diameter on machine productivity at clearance of $5 \mathrm{~mm}$, moisture-content of $10 \%$, cutting-knives speed of $450 \mathrm{rpm}$ and feeding-drums speed of $10 \mathrm{rpm}$.

Fig. 8 shows the effect of tree-branches diameter, chopping-knives speed and concave-hole diameter on machine productivity.

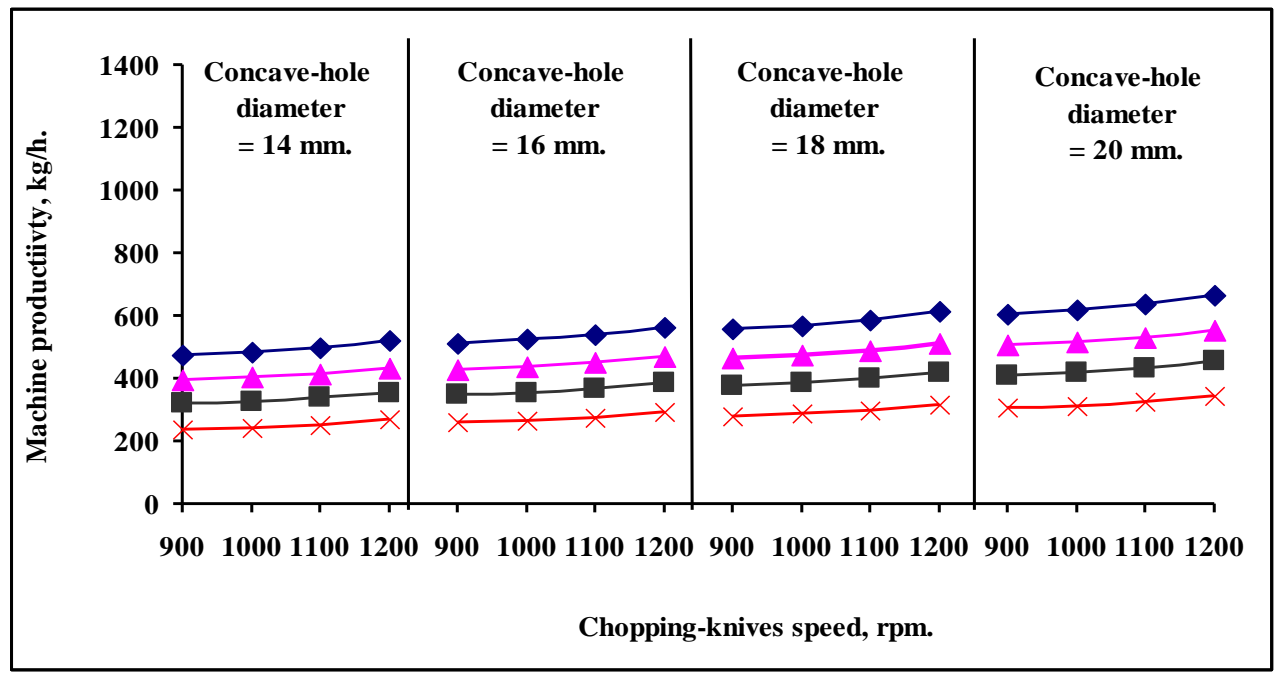

Tree-branches mm.

$-\bullet \mathbf{2 0}+\mathbf{3 0} \rightarrow \mathbf{4 0} \leftarrow \mathbf{5 0}$

Fig. 8: Effect of tree-branches diameter, chopping-knives speed and concave-hole diameter on machine productivity by using clearance of $5 \mathrm{~mm}$ and branches moisture-content of $10 \%$.

The minimum productivity of $238 \mathrm{~kg} / \mathrm{h}$ was obtained by using choppingknives speed of $900 \mathrm{rpm}(27.31 \mathrm{~m} / \mathrm{s})$, concave-hole diameter of $14 \mathrm{~mm}$ and tree-branch diameter of $50 \mathrm{~mm}$. Meanwhile, the maximum machine productivity of $667 \mathrm{~kg} / \mathrm{h}$ was obtained by using chopping-knives speed of $1200 \mathrm{rpm}(36.92 \mathrm{~m} / \mathrm{s})$, concave-hole diameter of $20 \mathrm{~mm}$ and tree-branch diameter of $20 \mathrm{~mm}$ (at constant clearance of $5 \mathrm{~mm}$, moisture-content of $10 \%$, cutting-knives speed of $450 \mathrm{rpm}$ and feeding-drums speed of 10 rpm). 
(4) Effect of tree-branch diameter, chopping-knives speed, concave hole-diameter on power requirement and specific energy at clearance of $5 \mathrm{~mm}$, moisture-content of $10 \%$, cutting-knives speed of $450 \mathrm{rpm}$ and feeding-drums speed of $10 \mathrm{rpm}$.

Fig. 9 shows the effect of tree-branches diameter, chopping-knives speed and concave-hole diameter on power requirement and specific energy.

The maximum power requirement of $14.6 \mathrm{~kW}$ was obtained by using chopping-knives speed of $1200 \mathrm{rpm}(36.92 \mathrm{~m} / \mathrm{s})$, concave-hole diameter of $14 \mathrm{~mm}$ and tree-branch diameter of $50 \mathrm{~mm}$. Meanwhile, the minimum power requirement of $11.3 \mathrm{~kW}$ was obtained by using chopping-knives speed of $900 \mathrm{rpm}(27.31 \mathrm{~m} / \mathrm{s})$, concave-hole diameter of $20 \mathrm{~mm}$ and treebranch diameter of $20 \mathrm{~mm}$ (at constant clearance of $5 \mathrm{~mm}$, moisturecontent of $10 \%$, cutting-knives speed of $450 \mathrm{rpm}$ and feeding-drums speed of $10 \mathrm{rpm})$.

The maximum power specific energy of $56.8 \mathrm{~kW} . \mathrm{h} /$ ton was obtained by using chopping-knives speed of $900 \mathrm{rpm}(27.31 \mathrm{~m} / \mathrm{s})$, concave-hole diameter of $14 \mathrm{~mm}$ and tree-branch diameter of $50 \mathrm{~mm}$. Meanwhile, the minimum specific energy of $18.4 \mathrm{~kW} . \mathrm{h} / \mathrm{ton}$ was obtained by using chopping-knives speed of $1200 \mathrm{rpm}(36.92 \mathrm{~m} / \mathrm{s})$, concave-hole diameter of $20 \mathrm{~mm}$ and tree-branch diameter of $20 \mathrm{~mm}$ (at constant clearance of 5 $\mathrm{mm}$, moisture-content of $10 \%$, cutting-knives speed of $450 \mathrm{rpm}$ and feeding-drums speed of $10 \mathrm{rpm}$ ).

(5) Effect of tree-branch diameter concave hole-diameter on operation and production costs at tree-branches moisture content of $10 \%$, feeding-drums speed of $10 \mathrm{rpm}(0.083 \mathrm{~m} / \mathrm{s})$, cuttingknives speed of $450 \mathrm{rpm}(8.47 \mathrm{~m} / \mathrm{s})$, chopping-knives speed of 1100 $\mathrm{rpm}(33.38 \mathrm{~m} / \mathrm{s})$ and clearance of $5 \mathrm{~mm}$.

Table 4 shows the components of the Awady equation and operation and production costs of using the designed granular processing-machine.

Table 4: The components of Awady equation.

\begin{tabular}{|c|c|c|c|c|c|c|c|c|}
\hline p, L.E. & $\mathrm{h}, \mathrm{h}$ & $\begin{array}{c}\mathrm{a}, \\
\text { year }\end{array}$ & $\mathrm{i}$ & $\mathrm{t}$ & $\mathrm{r}$ & $\mathrm{Ec}, \mathrm{kW} . \mathrm{h} / \mathrm{h}$ & $\begin{array}{c}\mathrm{Ep}, \\
\text { L.E. }\end{array}$ & $\begin{array}{c}\mathrm{m}, \\
\text { L.E }\end{array}$ \\
\hline 40000 & 30000 & 10 & 0.075 & 0.05 & 0.03 & $11.7-15$ & 0.30 & 1500 \\
\hline
\end{tabular}



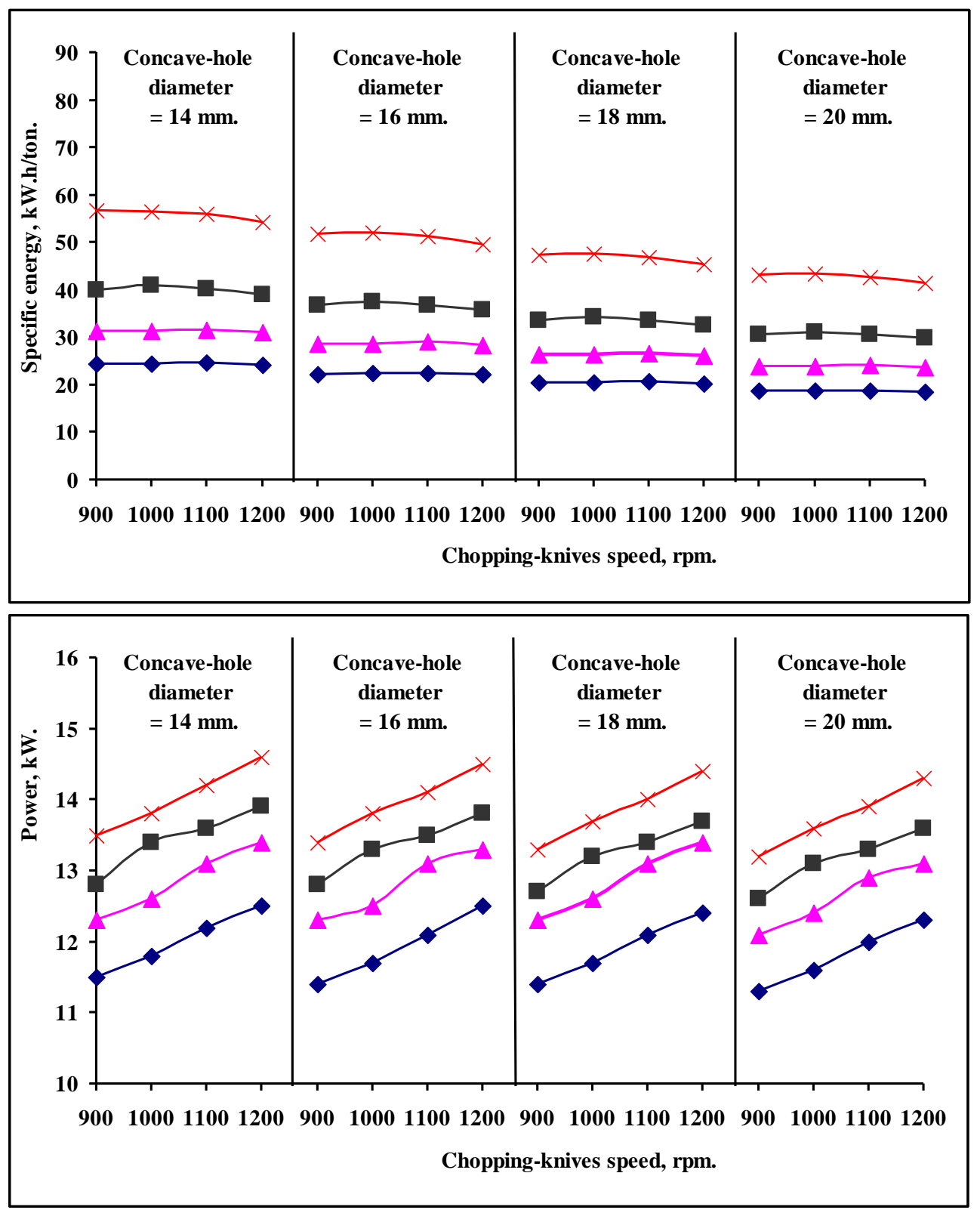

Tree-branches mm.

$\neg-20 \multimap-10-40 \div 50$

Fig. 9: Effect of tree-branches diameter, chopping-knives speed and concave-hole diameter on power requirement and specific energy using clearance of $5 \mathrm{~mm}$ and branches moisture-content of $10 \%$. 
Table 5 shows the effect of concave-hole diameter and tree-branches diameter on operation and production costs at moisture content of $10 \%$, feeding-drums speed of $10 \mathrm{rpm}(0.083 \mathrm{~m} / \mathrm{s})$, cutting-knives speed of 450 $\mathrm{rpm}(8.47 \mathrm{~m} / \mathrm{s})$, chopping-knives speed of $1100 \mathrm{rpm}(33.38 \mathrm{~m} / \mathrm{s})$ and clearance of $5 \mathrm{~mm}$.

Table 5: Effect of concave-hole diameter and tree-branches diameter on operation and production costs at moisture content of $10 \%$, feeding-drums speed of $10 \mathrm{rpm}(0.083 \mathrm{~m} / \mathrm{s})$, cutting-knives speed of $450 \mathrm{rpm}(8.47 \mathrm{~m} / \mathrm{s})$, chopping-knives speed of 1200 $\mathrm{rpm}(36.42 \mathrm{~m} / \mathrm{s})$ and clearance of $5 \mathrm{~mm}$.

\begin{tabular}{|c|c|c|c|c|c|}
\hline $\begin{array}{c}\text { Concave- } \\
\text { hole } \\
\text { diameter, } \\
\text { mm. }\end{array}$ & $\begin{array}{c}\text { Tree- } \\
\text { branches } \\
\text { diameter, } \\
\text { mm. }\end{array}$ & $\begin{array}{c}\text { Power, } \\
\text { kW. }\end{array}$ & $\begin{array}{l}\text { Operation } \\
\text { cost, } \\
\text { L.E./h. }\end{array}$ & $\begin{array}{c}\text { Machine } \\
\text { productivity, } \\
\mathrm{kg} / \mathrm{h} .\end{array}$ & $\begin{array}{l}\text { Production } \\
\text { cost, } \\
\text { L.E./h. }\end{array}$ \\
\hline \multirow{4}{*}{14} & 20 & 12.4 & 17.42 & 519 & 33.56 \\
\hline & 30 & 13.3 & 18.14 & 433 & 41.89 \\
\hline & 40 & 13.8 & 18.41 & 356 & 51.70 \\
\hline & 50 & 14.4 & 18.56 & 269 & 68.98 \\
\hline \multirow{4}{*}{16} & 20 & 12.34 & 18.74 & 564 & 33.22 \\
\hline & 30 & 13.25 & 18.12 & 470 & 38.55 \\
\hline & 40 & 13.67 & 18.39 & 387 & 47.52 \\
\hline & 50 & 14.3 & 18.52 & 293 & 63.20 \\
\hline \multirow{4}{*}{18} & 20 & 12.26 & 18.71 & 613 & 30.52 \\
\hline & 30 & 13.33 & 18.09 & 511 & 35.41 \\
\hline & 40 & 13.59 & 18.42 & 420 & 43.85 \\
\hline & 50 & 14.21 & 18.49 & 318 & 58.16 \\
\hline \multirow{4}{*}{20} & 20 & 12.19 & 18.68 & 667 & 28.01 \\
\hline & 30 & 13.1 & 18.07 & 556 & 32.51 \\
\hline & 40 & 13.5 & 18.35 & 457 & 40.15 \\
\hline & 50 & 14.15 & 18.47 & 346 & 53.37 \\
\hline
\end{tabular}


The maximum operation cost of 18.71 L.E./h was obtained by using concave-hole diameter of $18 \mathrm{~mm}$ and tree-branch diameter of $20 \mathrm{~mm}$. Meanwhile, the minimum operation cost of of 17.42 L.E./h was obtained by using concave-hole diameter of $14 \mathrm{~mm}$ and tree-branch diameter of 20 $\mathrm{mm}$ at moisture content of $10 \%$ feeding-drums speed of $10 \mathrm{rpm}(0.083$ $\mathrm{m} / \mathrm{s})$, cutting-knives speed of $450 \mathrm{rpm}(8.47 \mathrm{~m} / \mathrm{s})$, chopping-knives speed of $1100 \mathrm{rpm}(33.38 \mathrm{~m} / \mathrm{s})$ and clearance of $5 \mathrm{~mm}$.

The maximum production cost of 68.98 L.E./ton was obtained by using concave-hole diameter of $14 \mathrm{~mm}$ and tree-branch diameter of $50 \mathrm{~mm}$. Meanwhile, the minimum production cost of of 28.01 L.E./ton was obtained by using concave-hole diameter of $20 \mathrm{~mm}$ and tree-branch diameter of $20 \mathrm{~mm}$ at moisture content of $10 \%$ feeding-drums speed of $10 \mathrm{rpm}(0.083 \mathrm{~m} / \mathrm{s})$, cutting-knives speed of $450 \mathrm{rpm}(8.47 \mathrm{~m} / \mathrm{s})$, chopping-knives speed of $1100 \mathrm{rpm}(33.38 \mathrm{~m} / \mathrm{s})$ and clearance of $5 \mathrm{~mm}$.

\section{CONCLUSION}

The optimum conditions of a developed new-invented system for treebranches chopping were: moisture content of $10 \%$ feeding-drums speed of $10 \mathrm{rpm}(0.083 \mathrm{~m} / \mathrm{s})$, cutting-knives speed of $450 \mathrm{rpm}(8.47 \mathrm{~m} / \mathrm{s})$, chopping-knives speed of $1200 \mathrm{rpm}(33.38 \mathrm{~m} / \mathrm{s})$, clearance of $5 \mathrm{~mm}$, treebranch diameter range of $20-50 \mathrm{~mm}$ and concave-hole diameter range of $14-20 \mathrm{~mm}$. The results obtained at optimum conditions were: average chopping-length $=7-16 \mathrm{~mm}$, machine-productivity $=269-667 \mathrm{~kg} / \mathrm{h}$, power-requirement $=11.7-14.1 \mathrm{~kW}$, specific-energy $=18.4-54.2$ kW.h/ton and costs of $17.42-18.71$ L. E./h and $28.01-68.98$ L.E./ton.

\section{REFFERENCES}

Abede Alrahman, H. S., 2013, Development of locally manufactured hammer mill knives using finite element method, M. Sc., Dept. of Ag. Eng., Fac. of Ag., Cairo Univ.: 97-102.

Abo-Habaga, M. M.; Yehia, I. and Abo-Elasaad, G. A., 2015, Development of a rice straw bales chopper, J.Soil Sci. and Agric. Eng., Mansoura Univ., Vol. 6 (10): 1249 - 1262. 


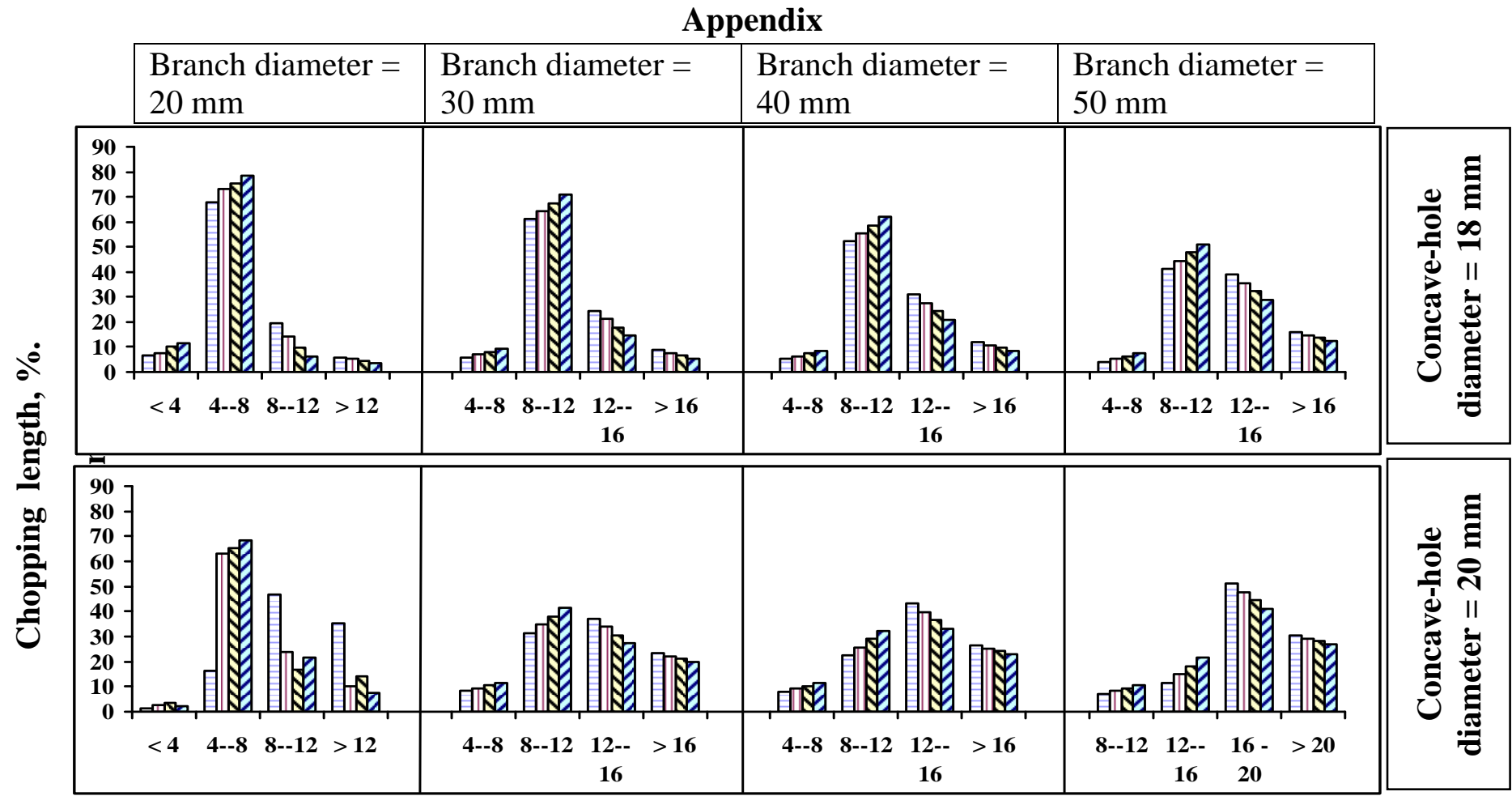

Chopping-length category, $\mathrm{mm}$.

Chopping-knives speed, rpm.

\section{曰900 四 $1000 \mathbf{\nabla} 1100 \mathbb{Z} 1200$}

Fig. A-1: Effect of chopping-knives speed and tree-branch diameter on chopping-length percentage at concave hole-diameter of 18 and $20 \mathrm{~mm}$. 
Abo-Elasaad, G. A., 2016, Development of a rice straw bales chopper, M. Sc., Dept. of Ag. Mech., Fac. of Agriculture, Mansoura Univ.: 47 79

Ahmed, H. M., 2013, Development of grinding machine suitable for horticultural by-products, M. Sc., Dept. of Ag. Eng., Fac. of Agriculture, Cairo Univ.: 85-95.

Awady, M. N., 1978, Tractors and farm machines, in Arabic, text. Col. Ag., A. Shams U.: 164-167.

Bulletin of Central Administration for Agricultural Extension Service in 2015, in Arabic.

FAO, 2008, Animal production based on crop residues processing machines, Corporate Document, Repository, Ag. and Consumer Protection, http://www.fao.org/DOCREP/005/Y1936E/y1936e0.htm

Ghanem, G. H. and Basiouny, M. A., 2010, Modifying a thresher for ensiling the green rice straw by shredding, Misr J. Ag. Eng., 27(2): 482-500.

Kurt, G., 1979, Engineering formulas, $3^{\text {rd }}$ Ed., MacGraw Hill Book N. Y.

Miu, P. I, Alvin, R. , Womac, A. R., Cannayen, I., Sokhansanj, S.,. 2006, Analysis of biomass comminution and separation, processes in rotary equipment - a review, ASABE Ann. Int. Mtg Sponsored by ASABE Oregon Convention Center, Portland, Oregon, Paper No. 066169. St. Joseph, Mich.

Okasha E. M.,. Awad, A. E, and Hashem, F. R., 2015, Developing a machine for shredding wastes to protect the environment from pollution, Int. J. Chem. Tech. Res. 8(12): 797-805.

Schubert, G and Bernotat, S., 2004, Comminution of non-brittle materials. Int. J. of Mineral Proc., 74S:19-30. 
Woldt, D., Schubert, G. and Jäckel, H. G., 2004, Size reduction by means of low-speed rotary shears. Int. J. of Mineral Proc., 74S: 405-415

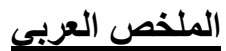

\section{تظوير نظام جديد مبتكر لفرم أفرع الأشجار}

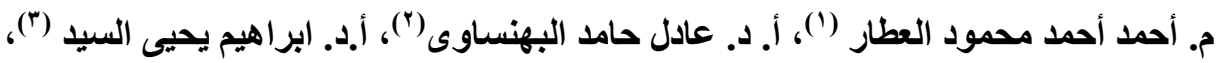

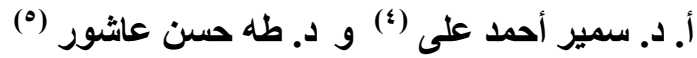

يهدف هذا البحث إلى تصميم نظام جديد مبتكر لفرم أفرع الأشجار ، مع دراسة العوامل المؤثرة

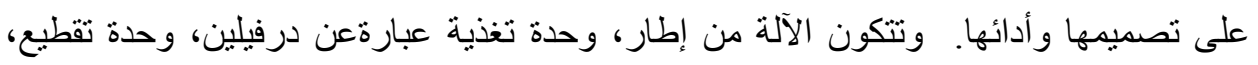

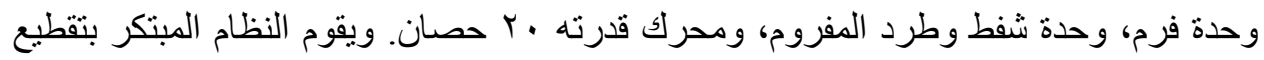

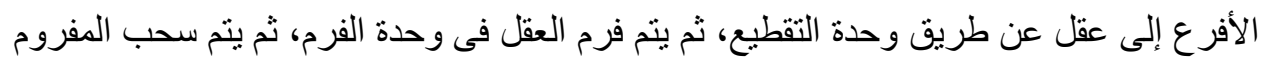

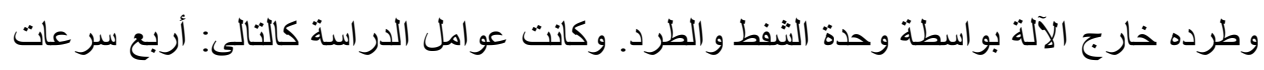

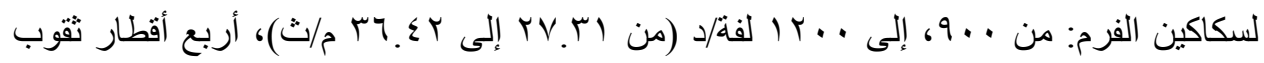

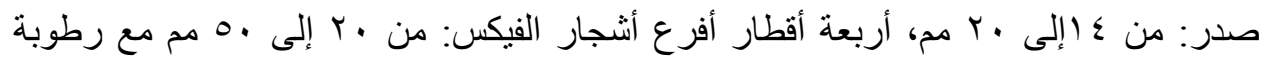

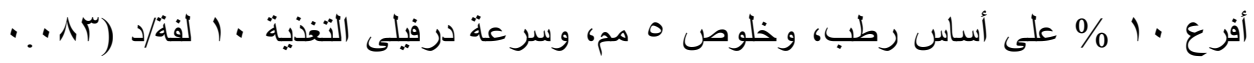

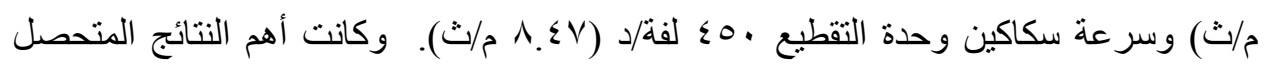
عليها كالتنالى:

(1) متوسط طول المفروم: وجد أن أعلى متوسط لطول المفروم هو 19 مم وتم الحصول عليه

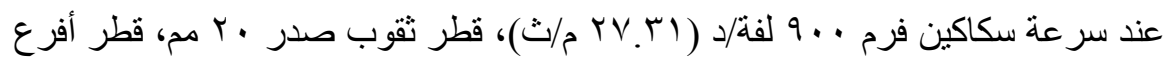

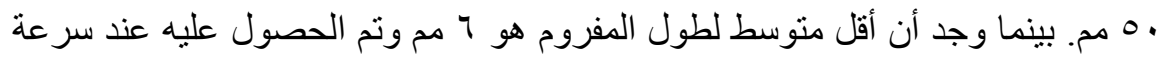

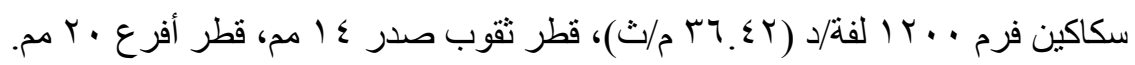

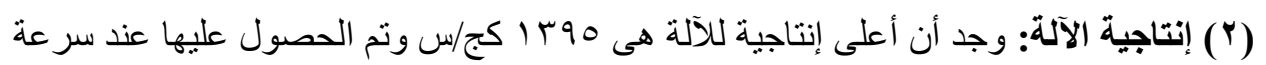

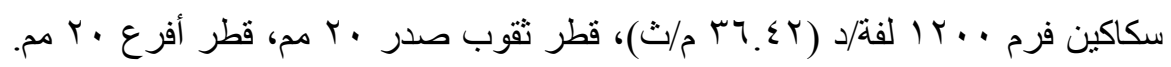

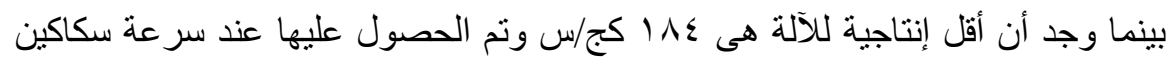

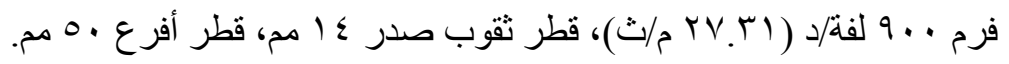

(1) مهندس بوزارة التموين والتجارة الداخلية ـ القاهرة.

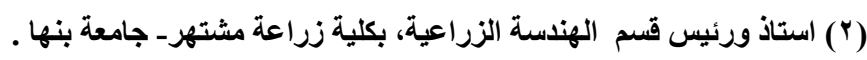

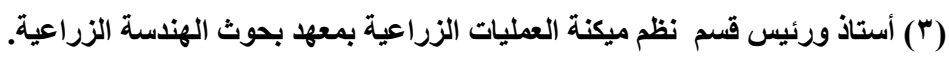

و (0) (ستاذ، قسم الهندسة الزراعية بكلية زراعة مشتهر - جامعة بنها. 


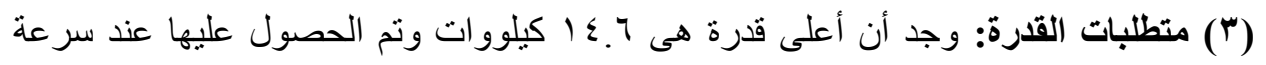

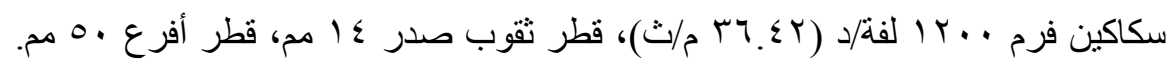

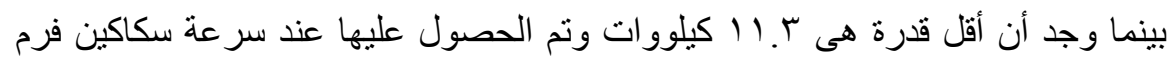

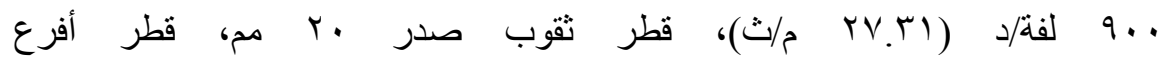
r.

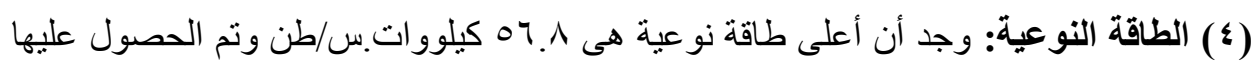

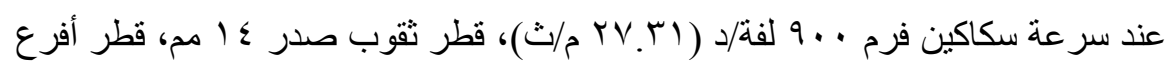

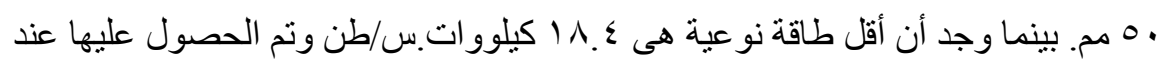

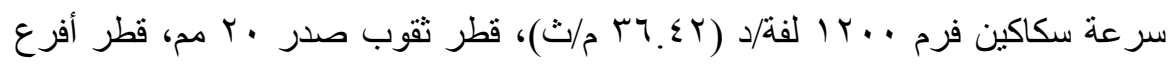

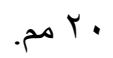
(0) تكاليف تثغيل الآلة: تراوحت التكاليف المتحصل عليها عند أنسب سرعة سكاكين فرم

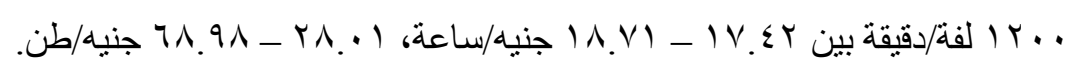

